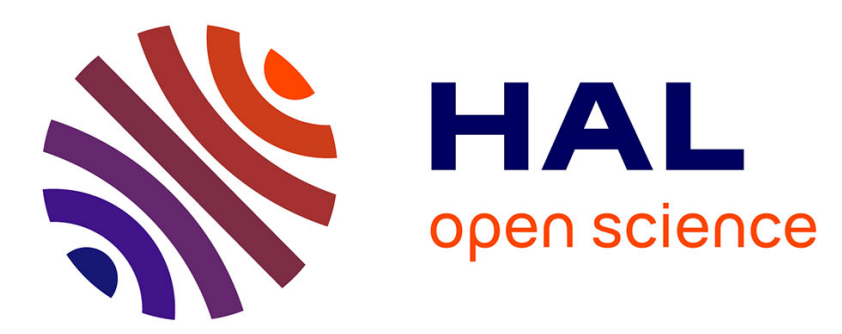

\title{
Self-Complementary and Narcissistic Self-Sorting of bis-Acridinium Tweezers
}

Henri-Pierre Jacquot de Rouville, Christophe Gourlaouen, Valérie Heitz

\section{To cite this version:}

Henri-Pierre Jacquot de Rouville, Christophe Gourlaouen, Valérie Heitz. Self-Complementary and Narcissistic Self-Sorting of bis-Acridinium Tweezers. Dalton Transactions, 2019, 48, pp.8725 - 8730. 10.1039/C9DT01465A . hal-02156211

\section{HAL Id: hal-02156211 https://hal.science/hal-02156211}

Submitted on 14 Jun 2019

HAL is a multi-disciplinary open access archive for the deposit and dissemination of scientific research documents, whether they are published or not. The documents may come from teaching and research institutions in France or abroad, or from public or private research centers.
L'archive ouverte pluridisciplinaire HAL, est destinée au dépôt et à la diffusion de documents scientifiques de niveau recherche, publiés ou non, émanant des établissements d'enseignement et de recherche français ou étrangers, des laboratoires publics ou privés. 


\section{Journal Name}

\section{ARTICLE}

\section{Self-Complementary and Narcissistic Self-Sorting of bis-Acridinium Tweezers}

Received 00th January 20xx, Accepted 00th January 20xx

DOI: $10.1039 / \times 0 x \times 00000 x$

www.rsc.org/

\author{
Henri-Pierre Jacquot de Rouville, ${ }^{* a}$ Christophe Gourlaouen ${ }^{a}$ and Valérie Heitz ${ }^{* a}$
}

A molecular tweezer incorporating two acridinium moieties linked by a 1,3-dipyridylbenzene spacer was synthesized in three steps. The formation of its self-complementary dimer in water was demonstrated as the result of $\pi-\pi$ stacking and hydrophobic interactions. Moreover, a 1:1 mixture of this bis-acridinium tweezer with one build on a 2,6-diphenylpyridyl spacer evidenced a narcissistic self-sorting behaviour in water.
Biological systems perform complex functions (transmission of information, chemical transformations, transport, regulation) on account of reversible interactions between biomolecules. ${ }^{1}$ The selective formation of functional aggregates relies on very efficient self-sorting processes arising from complex mixtures. The efficiency of these self-sorting processes is encoded in the shape and the functional groups in each components of the involved partners. In the field of supramolecular chemistry, the comprehension of molecular recognition and self-assembly phenomena ${ }^{2}$ gave rise to architectures of increasing complexity in order to mimic various biological functions. Interestingly, the self-association of identical complementary units represents the simplest way to achieve complex structures endowed with functions. Among the systems able to self-associate, those involving $\pi-\pi$ stacking interactions between complementary units have been less reported. ${ }^{3}$

The interest in self-sorting processes in order to organize functional systems has emerged more recently. ${ }^{4}$ According to Isaacs et al., self-sorting was defined as the high fidelity recognition between species within complex mixtures. ${ }^{5}$ Two assembling processes can be foreseen for these systems: (i) narcissistic self-sorting (if molecules self-recognize) and (ii) social self-sorting (if molecules specifically interact with partners). For both types of behaviour, the equilibrium is either driven thermodynamically (thermodynamic self-sorting) or kinetically (kinetic self-sorting). The outcome of the self-sorting processes can be directed by several parameters -also called molecular codes. ${ }^{6}$ Among molecular codes used in self-sorting systems, geometrical complementary (size and shape), ${ }^{7}$ complementarity in hydrogen-bonds, ${ }^{8}$ steric effects, ${ }^{9}$ coordination sphere in metal-ligand interactions ${ }^{10}$ and chargetransfer ${ }^{11}$ can be cited. In this context, rare examples of self-

\footnotetext{
a. Institut de Chimie de Strasbourg, UMR 7177-CNRS, Université de Strasbourg, Institut Le Bel, 4 rue Blaise Pascal, 67008 Strasbourg, France. E-mail: v.heitz@unistra.fr, hpjacquot@unistra.fr

+ Footnotes relating to the title and/or authors should appear here.

Electronic Supplementary Information (ESI) available: [details of any supplementary information available should be included here]. See DOI: 10.1039/x0xx00000x
}

sorting tweezer-shaped compounds of similar shape and size have been reported. ${ }^{12}$

We recently described the synthesis of a self-complementary bis-acridinium tweezer $(\mathbf{1 \cdot 2} \mathbf{C l}$ ) in a five-step synthesis (Scheme 1). ${ }^{13}$ This tweezer has shown to self-assemble into an entwined dimer in acetonitrile and water. More especially, two acridinium moieties acting as electron-deficient recognition units were able to interact through $\pi-\pi$ stacking interactions with the 2,6diphenylpyridyl spacer of a second tweezer. In water, the complete shift of the equilibrium towards the dimer $(1)_{2} \cdot 4 \mathrm{Cl}$ was the result of hydrophobic interactions as demonstrated by ${ }^{1} \mathrm{H}$ NMR experiments (variable temperature and concentration studies, NOESY and DOSY experiments).

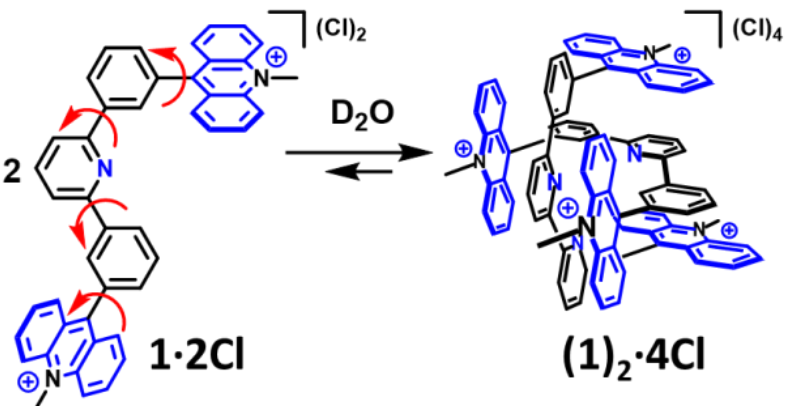

Scheme 1 Molecular tweezer $\mathbf{1 . 2} \mathrm{Cl}$ dimerizing in water. ${ }^{13}$

We envisioned that a new self-complementary tweezer incorporating a 1,3-dipyridylbenzene spacer $(\mathbf{2} \cdot \mathbf{2} \mathrm{Cl}$ ) could lead to interesting self-association processes governed by the different electronic properties of the spacer. In comparison to $1 \cdot 2 \mathrm{Cl}$, the relative positions of the nitrogen atoms in the spacer of $2 \cdot 2 \mathrm{Cl}$ should not alter the optimum distance for $\pi$ - $\pi$ stacking interactions $(7.1 \AA)$ between both acridinium units. ${ }^{14}$ In the present work, we report (i) the synthesis of a new bis-acridinium tweezer, (ii) the characterization of its self-association into an entwined dimer in water and (iii) the study of a 1:1 mixture of this new tweezer with our previously reported one $(\mathbf{1 \cdot 2} \mathbf{C l})^{13}$ resulting in a narcissistic self-sorting process. 
The synthesis of the targeted receptor $\mathbf{2 \cdot 2} \mathbf{C l}$ bearing two acridinium moieties was achieved according to a shorter synthetic path than for $\mathbf{1 \cdot 2} \mathbf{C l}$ (three-step vs. five-step synthesis, Scheme 2). ${ }^{15}$ The bis-boronic ester derivative (3) was prepared in $96 \%$ yield starting from 1,3-dibromobenzene as previously reported. ${ }^{16}$ Compound $\mathbf{3}$ was then allowed to react in a palladium-catalysed $\mathrm{C}_{\mathrm{sp2} 2}-\mathrm{C}_{\mathrm{sp2} 2}$ coupling with 2,6dibromopyridine (4 eq.) in the presence of $\mathrm{Pd}\left(\mathrm{PPh}_{3}\right)_{4}(10 \%)$ and $\mathrm{K}_{2} \mathrm{CO}_{3}(2 \mathrm{~N})$ in Toluene/EtOH/water. After purification using column chromatography, the corresponding bis-bromopyridyl derivative (4) was isolated in 53\% yield. Finally, halogen-metal exchange on 4 ( 1 eq.) using $n$-BuLi ( 2 eq.) in hexanes $(2.5 \mathrm{M})$, followed by addition of 10 -methyl- $9(10 \mathrm{H})$-acridone at $-78^{\circ} \mathrm{C}(2$ eq.) led to the corresponding bis-acridane intermediate. Aromatization of this intermediate was performed using a solution of $\mathrm{HCl}$ ( 37 wt. \%). Purification was carried out by anion metathesis using $\mathrm{KPF}_{6}$ and filtration. Then, the bis-acridinium receptor $\left(\mathbf{2} \cdot \mathbf{2} \mathbf{P F}_{6}\right)$ was converted to the corresponding chloride salt $\mathbf{2 \cdot 2} \mathbf{C l}$ using tetrabutylammonium chloride (TBACl) in acetone. The desired tweezer $\mathbf{2 \cdot 2} \mathbf{C l}$ was obtained as a yellowish solid in $30 \%$ yield from $4 .{ }^{17}$

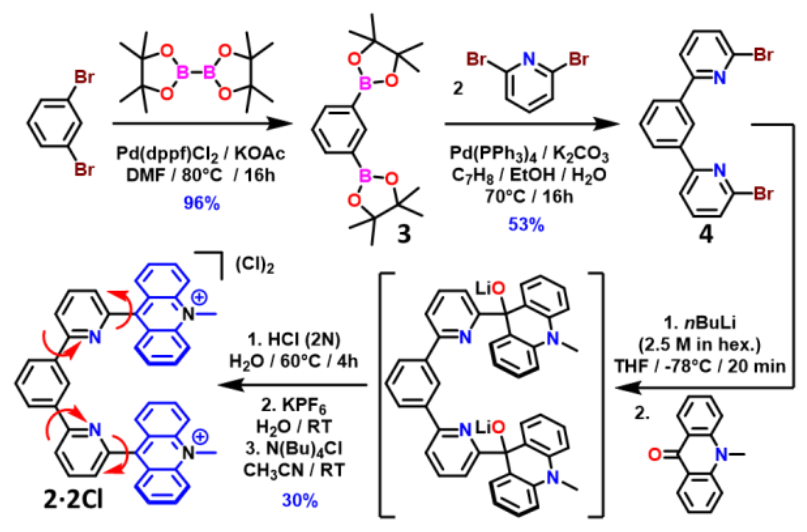

Scheme $\mathbf{2}$ Three-step synthesis of $\mathbf{2 \cdot 2} \mathbf{C l}$ starting from 1,3-dibromobenzene.

All ${ }^{1} \mathrm{H}$ NMR spectrum signals of $\mathbf{2 \cdot 2 C l}$ (DMSO- $d_{6}, 298 \mathrm{~K}$ ) were assigned using 2D NMR experiments (see ESI). Comparison of the ${ }^{1} \mathrm{H}$ NMR spectrum of $\mathbf{2} \cdot \mathbf{2} \mathrm{Cl}\left(c=3 \times 10^{-3} \mathrm{~mol} \mathrm{~L}^{-1}\right)$ to our previously reported bis-acridinium receptor $\mathbf{1 . 2 C l}$ showed analogous chemical shifts for the acridinium protons $\left(\delta\left(\mathrm{H}_{1 / 8}\right)=\right.$ $7.98, \delta\left(\mathrm{H}_{2 / 7}\right)=7.88, \delta\left(\mathrm{H}_{3 / 6}\right)=8.45$ and $\delta\left(\mathrm{H}_{4 / 5}\right)=8.90 \mathrm{ppm}$, see Fig. 1a-b). ${ }^{13}$ This observation suggests that the acridinium protons of $\mathbf{2} \cdot \mathbf{2} \mathrm{Cl}$ are not affected by the electronic environment of the aromatic ring (phenyl or pyridyl) at their 9-position. Moreover, the spectrum of $\mathbf{2 \cdot 2} \mathbf{C l}$ did not show any signals related to the presence of its corresponding dimer as observed in $1.2 \mathrm{Cl}$ thus suggesting the dimer formation is less energetically favoured for $(\mathbf{2})_{2} \cdot \mathbf{4 C l}$ than for $(\mathbf{1})_{2} \cdot \mathbf{4 C l}$. As observed for $\mathbf{1} \cdot \mathbf{2} \mathrm{Cl}$, we envisioned that hydrophobic interactions would conduct to the formation of the dimer $(2)_{2} \cdot 4 \mathbf{C l}$. Solutions of $\mathbf{2} \cdot \mathbf{2} \mathrm{Cl}\left(c=3 \times 10^{-3}\right.$ $\mathrm{mol} \mathrm{L}^{-1}$ ) were recorded with an increasing percentage of $\mathrm{D}_{2} \mathrm{O}$ in DMSO- $d_{6}$ (from $0 \%$ to $100 \%$, see Fig. S2.23). Upon increasing the amount of $\mathrm{D}_{2} \mathrm{O}$, the proton signals broadened out and were upfield shifted, indicative of dynamic processes involving selfassociation. In pure $\mathrm{D}_{2} \mathrm{O}$, the spectrum of a single discrete species was revealed exhibiting upfield-shifts of all protons (Fig. 1d). Noteworthy, chemical shifts of the acridinium protons of (2) $)_{2} \cdot 4 \mathrm{Cl}\left(\delta\left(\mathrm{H}_{1 / 8}\right)=7.26, \delta\left(\mathrm{H}_{2 / 7}\right)=7.32, \delta\left(\mathrm{H}_{3 / 6}\right)=8.16\right.$ and $\Delta \delta\left(\mathrm{H}_{4 / 5}\right)$ $=8.48 \mathrm{ppm}$ ) are similar to $(\mathbf{1})_{2} \cdot \mathbf{4 C l}$ in water (Fig. 1c-d). This observation suggests that the newly species is the result of the

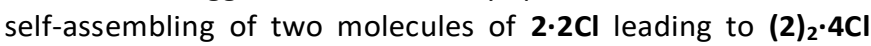
with an average $D_{2 \mathrm{~d}}$ symmetry.

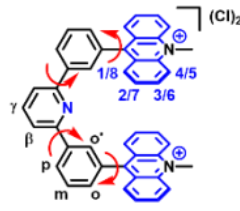

$1 \cdot 2 \mathrm{Cl}$

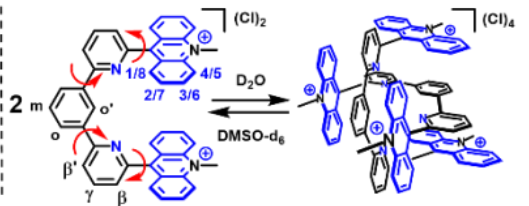

$2 \cdot 2 \mathrm{Cl}$

$(2) \cdot 4 \mathrm{Cl}$

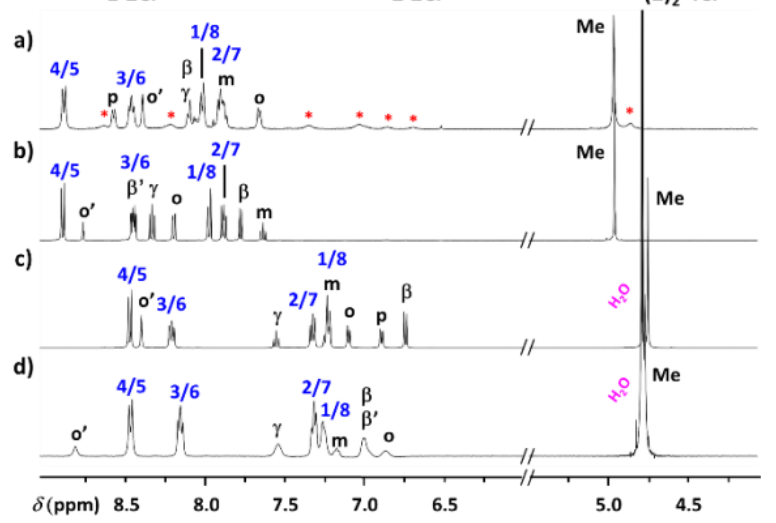

Fig. $\left.{ }^{1} \mathrm{H} \mathrm{NMR}\left(400 \mathrm{MHz}, 298 \mathrm{~K}, \mathrm{c}=3 \times 10^{-3} \mathrm{~mol} \mathrm{~L}^{-1} \text { ) spectra of (a) } \mathbf{1} \cdot \mathbf{2} \mathrm{Cl} \text { (*traces of (1) }\right)_{2} \cdot 4 \mathrm{Cl}\right)$ and of (b) $2 \cdot 2 \mathrm{Cl}$ in DMSO- $d_{6}$ and of (c) $(1)_{2} \cdot 4 \mathrm{Cl}$ and of (d) $(2)_{2} \cdot 4 \mathrm{Cl}$ in $\mathrm{D}_{2} \mathrm{O}$.

This hypothesis was first corroborated by ${ }^{1} \mathrm{H}-{ }^{1} \mathrm{H}$ ROESY experiments (Fig. 2). Cross peaks between the outer benzene protons $\left(\mathrm{H}_{\circ}\right.$ and $\left.\mathrm{H}_{m}\right)$ and the methyl protons of the acridinium moieties were observed. These through-space correlations can be best interpreted in terms of the close proximity of the central 2,6-dipyridylbenzene spacer and the acridinium moieties. This observation can be best interpreted in terms of $\pi-\pi$ interactions existing between all aromatic moieties of the molecule. As seen for the entwined dimer formed with $\mathbf{1 \cdot 2} \mathbf{C l}$, the cone of anisotropy of these moieties within the dimer affect each other thus explaining the observed chemical shifts in the ${ }^{1} \mathrm{H} N M R$ spectrum of $(2)_{2} \cdot 4 \mathrm{Cl}^{13}$ Further evidence of the formation of the dimer (2) $)_{2} \cdot 4 \mathrm{Cl}$ was given by DOSY experiments (see the ESI, Fig. $\mathrm{S} 2.19)$. Experiments recorded in $\mathrm{D}_{2} \mathrm{O}\left(c=1 \times 10^{-2} \mathrm{~mol} \mathrm{~L}^{-1}, 298 \mathrm{~K}\right)$ showed that all protons have the same diffusion coefficient and correspond to a unique diffusing species. From the obtained diffusion coefficient $(D)$ of $279 \mu \mathrm{m}^{2} \mathrm{~s}^{-1}$, the calculated hydrodynamic radius $\left(R_{H}\right)$ was found to be $6.9 \AA$. The same value was estimated for the hydrodynamic radius of the monomer, $\mathbf{2} \cdot \mathbf{2 C l}$ in DMSO- $d_{6}\left(R_{\mathrm{H}}=6.9 \AA ; D=145 \mu \mathrm{m}^{2} \mathrm{~s}^{-1}\right.$, see the ESI, Fig. S2.11) attesting the good geometrical fit of the tweezer within the dimer. Noteworthy, these hydrodynamic radii are similar, within the experimental error of $5 \%$, to the calculated hydrodynamic radius obtained for $1.2 \mathrm{Cl}\left(R_{\mathrm{H}}=7.3 \AA\right.$; $D=263 \mu \mathrm{m}^{2} \mathrm{~s}^{-1}$ for $\left.(\mathbf{1})_{2} \cdot 4 \mathrm{Cl}\right)^{13}$ thus supporting the formation of $(2)_{2} \cdot 4 \mathrm{Cl}$ in water. $^{18}$ 


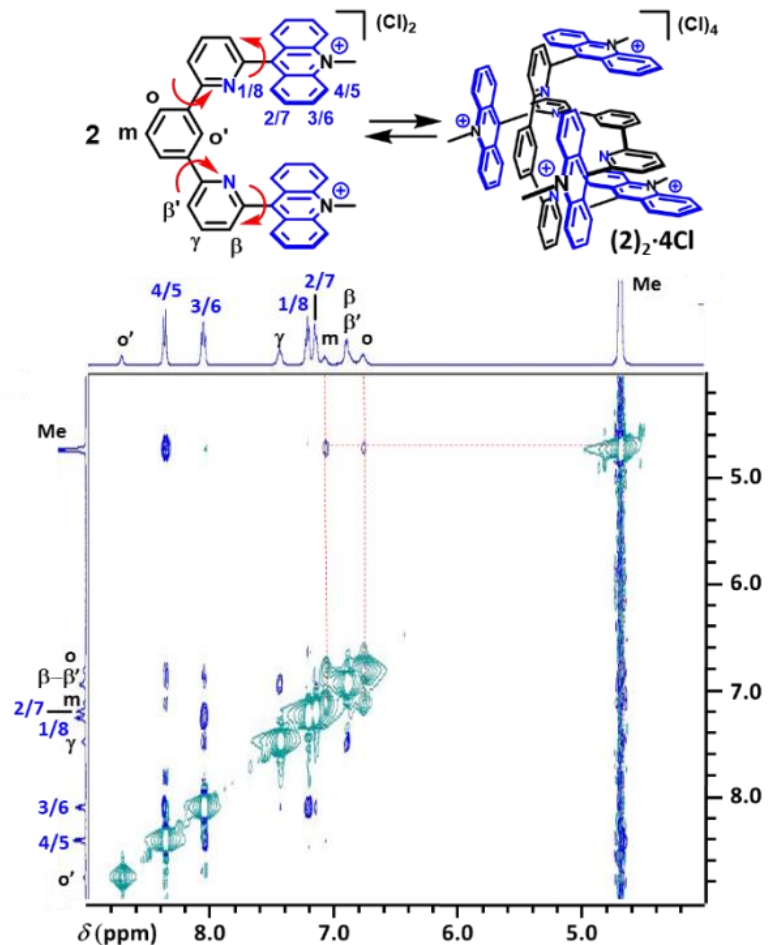

Fig. $2{ }^{1} \mathrm{H}-{ }^{1} \mathrm{H}$ ROESY $\left(500 \mathrm{MHz}, \mathrm{D}_{2} \mathrm{O}, 298 \mathrm{~K}, \mathrm{C}=1 \times 10^{-2} \mathrm{~mol} \mathrm{~L}^{-1}\right)$ spectrum of (2) $2 \cdot 4 \mathrm{Cl}$ Correlations between the $\mathrm{m}$ and o protons of the central pyridine with the methyl protons are highlighted.

Further insights into the monomer-dimer equilibrium were provided by ${ }^{1} \mathrm{H}$ NMR variable temperature experiments. $A$ solution of $2 \cdot 2 \mathrm{Cl}$ at a concentration of $1 \times 10^{-2} \mathrm{~mol} \mathrm{~L}^{-1}$ in $\mathrm{D}_{2} \mathrm{O}$ was heated from $278 \mathrm{~K}$ to $348 \mathrm{~K}$ (see ESI, Fig. S2.22). At any temperature, the same ${ }^{1} \mathrm{H}$ NMR spectrum of $(2)_{2} \cdot 4 \mathrm{Cl}$ was observed with a slight upfield shift of all proton signals attributed to a temperature effect. Consequently, the monomer-dimer equilibrium is exclusively driven to the dimeric form in water. In order to confirm this observation, variable concentration experiments were conducted in $\mathrm{D}_{2} \mathrm{O}$. From $10^{-2}$ to $5 \times 10^{-4} \mathrm{~mol} \mathrm{~L}^{-1}$, only signals corresponding to $(2)_{2} \cdot 4 \mathrm{Cl}$ were observed at $298 \mathrm{~K}$ and at $348 \mathrm{~K}$ (see ESI, Fig. S2.20-2.21). As previously postulated for $(1)_{2} \cdot 4 \mathrm{Cl}$, the high stability of $(2)_{2} \cdot 4 \mathrm{Cl}$ can be attributed to a shielding of the hydrophobic spacer from the aqueous environment by the $\pi$-cationic acridinium moieties. ${ }^{19}$

We were then interested in studying the mixture of the tweezers $\mathbf{1} \cdot \mathbf{2} \mathrm{Cl}$ and $\mathbf{2} \cdot \mathbf{2} \mathrm{Cl}$ of similar shape and size. Consequently, a $1: 1$ mixture of $\mathbf{1} \cdot \mathbf{2} \mathrm{Cl}$ and $\mathbf{2} \cdot \mathbf{2} \mathrm{Cl}$ in $\mathrm{D}_{2} \mathrm{O}\left(c=1 \times 10^{-2} \mathrm{~mol} \mathrm{~L}^{-1}\right.$, Fig. 3) was prepared. The ${ }^{1} \mathrm{H}$ NMR spectrum of the mixture showed the superposition of signals of both dimers $(\mathbf{1})_{2} \cdot 4 \mathrm{Cl}$ and $(\mathbf{2})_{2} \cdot \mathbf{4 C l}$ (no additional peaks detected) corresponding to a narcissistic self-sorting behaviour. Over a period of three weeks, no changes were observed thus suggesting the thermodynamic stability of the sample at room temperature. In order to confirm this self-sorting process, variable temperature experiments were performed in $\mathrm{D}_{2} \mathrm{O}$ (see ESI, Fig. S3.1-3.2). Upon successively heating $(348 \mathrm{~K})$ and cooling the sample $(298 \mathrm{~K})$, the previously monitored ${ }^{1} \mathrm{H}$ NMR spectrum were recorded at both temperatures (no traces of an hypothetical heteromeric dimer (1.2).4Cl were observed). Additionally, evaporation of the solvent and solubilisation of the mixture in DMSO- $d_{6}$ was performed. As demonstrated previously, DMSO- $d_{6}$ solvates each molecule in their corresponding monomers, namely $\mathbf{1 \cdot 2 \mathrm { Cl }}$ and $\mathbf{2} \cdot \mathbf{2} \mathbf{C l}$ (see ESI, Fig. S3.3). After evaporation of the solvent and solubilisation in $\mathrm{D}_{2} \mathrm{O}$, the recorded spectrum was identical to the former ${ }^{1} \mathrm{H}$ NMR spectrum in $\mathrm{D}_{2} \mathrm{O}$ (see ESI, Fig. S3.4). These additional experiments clearly demonstrate that this self-sorted mixture is under thermodynamic control. ${ }^{20}$ Consequently, it can be inferred that in $\mathrm{D}_{2} \mathrm{O}$, more than $95 \%$ of the mixture is composed of both dimers meaning that the association constant of $(\mathbf{1})_{2} \cdot \mathbf{4 C l}$ is at least ten times higher than that of $(2)_{2} \cdot 4 \mathrm{Cl}$.

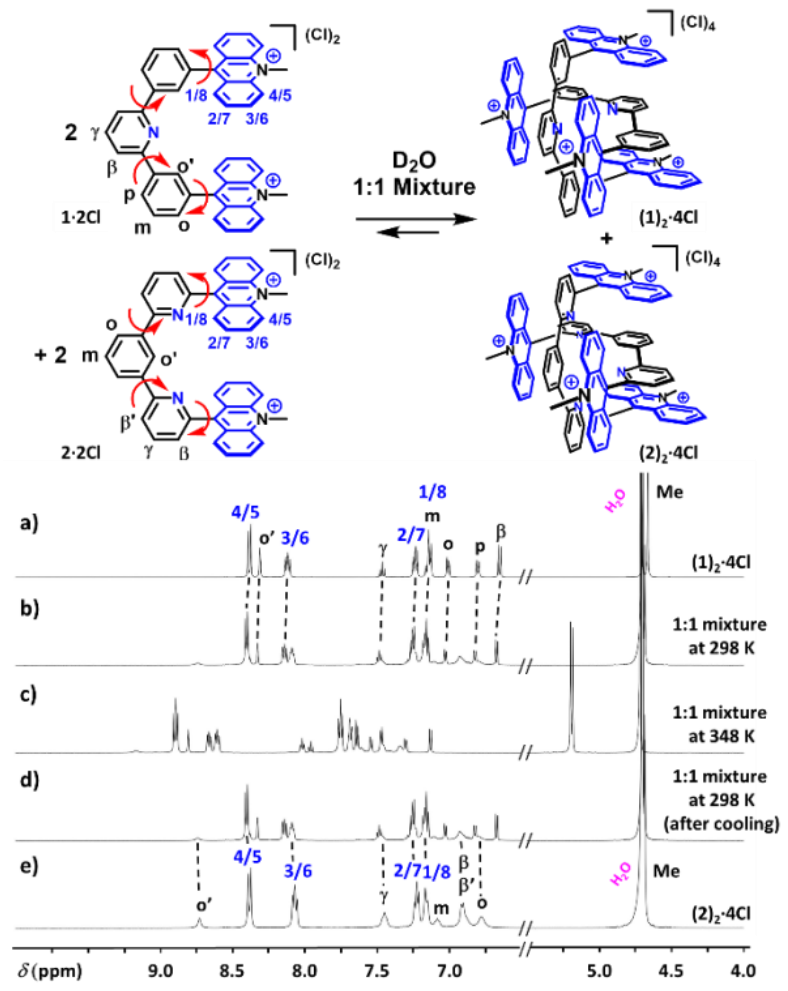

Fig. $3^{1} \mathrm{H}$ NMR (400 MHz, $\mathrm{D}_{2} \mathrm{O}, 298 \mathrm{~K}, \mathrm{c}=1 \times 10^{-2} \mathrm{~mol} \mathrm{~L}^{-1}$ ) spectra of (a) (1) $)_{2} \cdot 4 \mathrm{Cl}$, (b) a 1:1 mixture of (1) $)_{2} \cdot 4 \mathrm{Cl}$ and $(2)_{2} \cdot 4 \mathrm{Cl}$ at $298 \mathrm{~K}$, (c) the sample (b) after heating up at $348 \mathrm{~K}$ and (d) the sample (b) after cooling back at $298 \mathrm{~K}$ and (e) (2) $)_{2} \cdot 4 \mathrm{Cl}$.

To gain deeper understanding of this narcissistic self-sorting process, DFT investigations were undertaken on three tetracationic dimers $(\mathbf{1})_{\mathbf{2}^{4+}},(\mathbf{2})_{\mathbf{2}^{4+}}$ and $(\mathbf{1} \cdot \mathbf{2})^{4+}$ (Fig. 4). The optimized geometry of $(\mathbf{1})_{2^{4+}}$ is in good agreement with the previously reported solid state structure thus validating the method used. ${ }^{21}$ Even though similar torsion angles were found in all dimers, the distance between the two central aromatic rings of the spacers in $(\mathbf{2}) 2^{4+}(3.962 \AA)$ was shorter than in $(\mathbf{1})_{2}{ }^{4+}$ $(4.124 \AA)$ and in $(\mathbf{1 \cdot 2})^{4^{4+}}(4.289 \AA)$. The homomeric dimers $(\mathbf{1})_{2^{4+}}$ and $(2)_{2}{ }^{4+}$ formation exhibit the highest driving force $(\Delta G=-$ $24.9 \mathrm{kcal} \mathrm{mol}^{-1}$ and $-23.0 \mathrm{kcal} \mathrm{mol}^{-1}$ respectively) in comparison to the heteromeric dimer $(\mathbf{1} \cdot \mathbf{2})^{4+}\left(\Delta G=-22.3 \mathrm{kcal} \mathrm{mol}^{-1}\right)$. Consequently, the dissociation of both (1) $2^{4+}$ and $(2)_{2} 2^{4+}$ dimers to form two heteromeric dimers $(\mathbf{1 \cdot 2})^{4+}$ is endergonic $(\Delta G=+3.3$ 
$\mathrm{kcal} \mathrm{mol}-1$ ) thus confirming the thermodynamic origin of the self-sorting process. Further insights into the stabilization in $(\mathbf{1})_{2} \mathbf{4}^{4+}$ and $(2)_{2} \mathbf{4}^{++}$was given by non-covalent interaction analysis (Fig. 4). The observed stabilization for both homodimers in comparison to their monomers was attributed to van der Waals forces between the acridinium moieties of one monomer with the linker of a second monomer and to the existence of $[\mathrm{N} \cdots \mathrm{H}$ ] interactions between the inner hydrogen atoms of the linker of one monomer and the nitrogen atoms of the linker of a second monomer. These $[\mathrm{N} \cdots \mathrm{H}]$ interactions are partly electrostatic, tending towards the formation of hydrogen bonds. Remarkably, these $[\mathrm{N} \cdots \mathrm{H}]$ distances are shorter in $(\mathbf{1}) \mathbf{2}^{\mathbf{4 +}}$ than in $(\mathbf{2}) \mathbf{2}^{\mathbf{4 +}}$ suggesting a stronger binding between linkers in $(\mathbf{1})_{2^{4+}}$ in accordance with the highest driving force for the selfassociation of homodimer $(\mathbf{1})_{2}{ }^{4+}$.
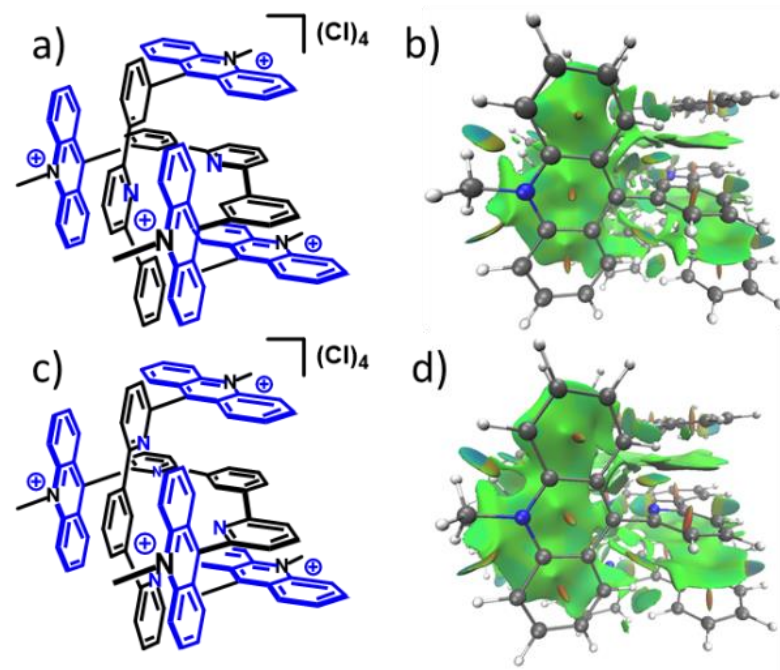

Fig. 4 Representations of (a) the entwined dimer of (1) $2^{4+}$, (b) non-covalent interaction analysis in the (1) $2^{4+}$ dimer, (c) of the entwined dimer of $(2)_{2} 2^{4+}$, (d) non-covalent interaction analysis in the $(2)_{2}{ }^{4+}$ dimer. In green are represented the van der Waals forces, in blue the attractive electrostatic forces and in red the steric congestion.

\section{Experimental Part}

Synthesis. All chemicals were of the best commercially available grade and used without further purification. 10-Methyl-9(10H)acridone and 1,3-bis(4,4,5,5-tetramethyl-1,3,2-dioxaborolan-2yl)benzene were synthesized according to previously reported procedure. ${ }^{16}$ All compounds were synthesized using schlenk technics and were fully characterized by $1 \mathrm{D}\left({ }^{1} \mathrm{H},{ }^{13} \mathrm{C}\left\{{ }^{1} \mathrm{H}\right\},{ }^{31} \mathrm{P}\left\{{ }^{1} \mathrm{H}\right\}\right.$ and ${ }^{19} \mathrm{~F}\left\{{ }^{1} \mathrm{H}\right\}$ ) and $2 \mathrm{D}$ (COSY, HSQC and HMBC) NMR experiments and by mass spectrometry experiments. DOSY spectra were generated by the DOSY module of the software Topspin to build the diffusion dimension. The diffusion coefficients were compared to DMSO or $\mathrm{H}_{2} \mathrm{O}$ as an internal standards ( $\eta$ (DMSO$\left.d^{6}\right)=2.18 \times 10^{-4}$ Pa.s and $\left.\eta\left(\mathrm{D}_{2} \mathrm{O}\right)=1.13 \times 10^{-3} \mathrm{~Pa} . \mathrm{s}\right)$. The hydrodynamic radius $\left(R_{H}\right)$ was calculated from the StokesEinstein equation assuming a spherical model ${ }^{22}$ and using predetermined solvent viscosity values. ${ }^{23}$

\section{1,3-Bis(6-bromopyridin-2-yl)benzene 4}

To a degassed solution of 2,6-dibromopyridine $(540 \mathrm{mg}, 2.28$ mmol, 3 eq.) and 1,3-bis(4,4,5,5-tetramethyl-1,3,2dioxaborolan-2-yl)benzene ${ }^{16} 3$ (250 $\mathrm{mg}, 0.76 \mathrm{mmol}$, 1eq.) in a toluene/ethanol mixture $(7 \mathrm{~mL}, 4: 3)$, was added $\mathrm{Pd}\left(\mathrm{PPh}_{3}\right)_{4}(87$ $\mathrm{mg}, 0.07 \mathrm{mmol}, 10 \%)$ and a degassed $2 \mathrm{~N}$ aqueous solution of $\mathrm{K}_{2} \mathrm{CO}_{3}(4 \mathrm{~mL})$. The reaction mixture was stirred at $90^{\circ} \mathrm{C}$ for 16 hours. The reaction mixture was then extracted with $\mathrm{Et}_{2} \mathrm{O}(3 \mathrm{x}$ $35 \mathrm{~mL}$ ) and the combined organic layers were dried $\left(\mathrm{MgSO}_{4}\right)$. After evaporation of solvents, the crude product was purified by column chromatography $\left(\mathrm{SiO}_{2}\right.$, cyclohexane $\left./ \mathrm{CH}_{2} \mathrm{Cl}_{2}-1: 1\right)$. The desired product 4 was obtained as a colorless solid in $53 \%$ yield (157 mg). $\left.{ }^{1} \mathrm{H} \mathrm{NMR} \mathrm{(400} \mathrm{MHz,} \mathrm{CDCl}_{3}, 298 \mathrm{~K}\right): \delta(\mathrm{ppm})=8.57(\mathrm{t}, J$ $\left.=1.5 \mathrm{~Hz}, 1 \mathrm{H}, \mathrm{H}_{\mathrm{o}^{\prime}}\right), 8.07\left(\mathrm{dd}, J=8.0,1.5 \mathrm{~Hz}, 2 \mathrm{H}, \mathrm{H}_{\mathrm{o}}\right.$ ), 7.79 (dd, $J=$ 8.0, $\left.1.0 \mathrm{~Hz}, 2 \mathrm{H}, \mathrm{H}_{\beta^{\prime}}\right), 7.63\left(\mathrm{t}, J=8.0 \mathrm{~Hz}, 2 \mathrm{H}, \mathrm{H}_{\gamma}\right), 7.58(\mathrm{t}, J=8.0 \mathrm{~Hz}$, $\left.1 \mathrm{H}, \mathrm{H}_{\mathrm{m}}\right), 7.45$ (dd, $\left.J=8.0,1.0 \mathrm{~Hz}, 2 \mathrm{H}, \mathrm{H}_{\beta}\right) .{ }^{13} \mathrm{C}\left\{{ }^{1} \mathrm{H}\right\} \mathrm{NMR}(100 \mathrm{MHz}$, $\left.\mathrm{CDCl}_{3}, 298 \mathrm{~K}\right): \delta(\mathrm{ppm})=158.1\left(\mathrm{~s}, \mathrm{C}_{\mathrm{Py}}\right), 142.1\left(\mathrm{~s}, \mathrm{C}_{\mathrm{C}-\mathrm{Br}}\right), 139.0(\mathrm{~s}$, $\left.C_{\gamma}\right), 138.3\left(s, C_{p h}\right), 129.3\left(s, C_{m}\right), 128.2\left(s, C_{o}\right), 126.6\left(s, C_{\beta}\right), 125.5$ $\left(\mathrm{s}, \mathrm{C}_{\mathrm{o}^{\prime}}\right), 119.2$ (s, $\left.\mathrm{C}_{\beta^{\prime}}\right)$. HRMS (ESI-TOF): for $\mathrm{C}_{16} \mathrm{H}_{11} \mathrm{Br}_{2} \mathrm{~N}_{3}, \mathrm{~m} / \mathrm{z}_{\text {calc }}=$ $388.9283, \mathrm{~m} / \mathrm{z}_{\text {found }}=388.9263\left(100 \%,[\mathrm{M}+\mathrm{H}]^{+}\right)$.

\section{Molecular Tweezer $\mathbf{2} \cdot \mathbf{2} \mathrm{Cl}$}

To a solution of 1,3-bis(6-bromopyridin-2-yl)benzene (4) (100 $\mathrm{mg}, 0.26 \mathrm{mmol}, 1$ eq.) in dry THF $(20 \mathrm{~mL})$, was added dropwise at $-78^{\circ} \mathrm{C}$ a solution of $n$-BuLi $(2.5 \mathrm{M}$ in hexanes, $0.20 \mathrm{~mL}, 0.51$ mmol, 2 eq.). After 20 minutes at $-78^{\circ} \mathrm{C}, 10$-methyl-9(10H)acridone (107 mg, $0.51 \mathrm{mmol}, 2$ eq.) was added dropwise. The mixture was further stirred at $-78^{\circ} \mathrm{C}$ for 2 hours, and allowed to room temperature overnight. After addition of a $2 \mathrm{~N}$ aqueous solution of $\mathrm{HCl}(30 \mathrm{~mL})$, the reaction mixture was poured into an aqueous solution of $\mathrm{KPF}_{6}(6 \mathrm{~g}$ in $150 \mathrm{~mL})$. The solid was washed with $\mathrm{H}_{2} \mathrm{O}(3 \times 100 \mathrm{~mL})$, solubilized in a minimum amount of $\mathrm{CH}_{3} \mathrm{CN}$ and poured into a saturated solution of tetrabutylammonium chloride (TBACl) in acetone $(10 \mathrm{~mL})$. After filtration, the desired product was washed with acetone and was isolated as a yellow oil in $30 \%$ yield $(55 \mathrm{mg})$.

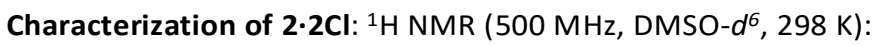
$\delta(\mathrm{ppm})=8.90\left(\mathrm{~d}, J=8.5 \mathrm{~Hz}, 4 \mathrm{H}, \mathrm{H}_{4 / 5}\right), 8.77\left(\mathrm{t}, J=1.5 \mathrm{~Hz}, 1 \mathrm{H}, \mathrm{H}_{\mathrm{o}^{\prime}}\right)$, $8.49-8.41\left(\mathrm{~m}, 8 \mathrm{H}, \mathrm{H}_{3 / 6-\beta^{\prime}}\right), 8.33\left(\mathrm{t}, J=7.5 \mathrm{~Hz}, 2 \mathrm{H}, \mathrm{H}_{\gamma}\right), 8.20(\mathrm{dd}, J$ $\left.=8.5,1.5 \mathrm{~Hz}, 2 \mathrm{H}, \mathrm{H}_{\mathrm{o}}\right), 7.98\left(\mathrm{dd}, J=8.5,1.5 \mathrm{~Hz}, 4 \mathrm{H}, \mathrm{H}_{1 / 8}\right.$ ), 7.89 (dd, $\left.J=8.5,1.5 \mathrm{~Hz}, 4 \mathrm{H}, \mathrm{H}_{2 / 7}\right), 7.78\left(\mathrm{dd}, J=7.5,1.0 \mathrm{~Hz}, 2 \mathrm{H}, \mathrm{H}_{\beta}\right), 7.64(\mathrm{t}$, $\left.J=8.5 \mathrm{~Hz}, 1 \mathrm{H}, \mathrm{H}_{\mathrm{m}}\right), 4.96(\mathrm{~s}, 6 \mathrm{H}, \mathrm{Me}) .{ }^{13} \mathrm{C}\left\{{ }^{1} \mathrm{H}\right\} \mathrm{NMR}(125 \mathrm{MHz}$, DMSO-d $\left.d^{6}, 298 \mathrm{~K}\right): \delta(\mathrm{ppm})=156.8\left(\mathrm{~s}, \mathrm{C}_{9}\right), 156.5\left(\mathrm{~s}, \mathrm{C}_{\mathrm{Py}}\right), 151.9(\mathrm{~s}$, $\left.\mathrm{C}_{\mathrm{Py}}\right), 141.6,138.7,138.5\left(\mathrm{~s}, \mathrm{C}_{\gamma}\right), 138.5\left(\mathrm{~s}, \mathrm{C}_{3 / 6}\right), 129.6\left(\mathrm{~s}, \mathrm{C}_{\mathrm{m}}\right)$, $129.1\left(\mathrm{~s}, \mathrm{C}_{1 / 8}\right), 128.3\left(\mathrm{~s}, \mathrm{C}_{\mathrm{o}}\right), 128.2\left(\mathrm{~s}, \mathrm{C}_{2 / 7}\right), 125.4\left(\mathrm{~s}, \mathrm{C}_{\mathrm{o}^{\prime}}\right), 125.0$ $\left(\mathrm{s}, \mathrm{C}_{\beta}\right), 121.7\left(\mathrm{~s}, \mathrm{C}_{\beta^{\prime}}\right), 119.4\left(\mathrm{~s}, \mathrm{C}_{4 / 5}\right), 39.1$ (s, Me). HRMS (ESI-TOF): for $\mathrm{C}_{44} \mathrm{H}_{32} \mathrm{~N}_{4}, \mathrm{~m} / \mathrm{z}_{\text {calc }}=308.1308, \mathrm{~m} / \mathrm{z}_{\text {found }}=308.1307(100 \%$, $\left.[\mathrm{M}]^{2+}\right)$. UV/Vis (DMSO, $\left.298 \mathrm{~K}\right): \lambda \max (\mathrm{nm})\left(\varepsilon\left(\mathrm{L} \cdot \mathrm{mol}^{-1} \cdot \mathrm{cm}^{-1}\right)\right)=$ 286 (28500), 354 (14650), 368 (22500), 408 (8300), 429 (9500), 454 (6650). Characterization of $(2)_{2} \cdot 4 \mathrm{Cl}:{ }^{1} \mathrm{H} \mathrm{NMR}(500 \mathrm{MHz}$, $\left.\mathrm{D}_{2} \mathrm{O}, 298 \mathrm{~K}\right): \delta(\mathrm{ppm})=8.78\left(\mathrm{br} \mathrm{s}, 1 \mathrm{H}, \mathrm{H}_{\mathrm{o}^{\prime}}\right), 8.43(\mathrm{~d}, J=9.0 \mathrm{~Hz}, 4 \mathrm{H}$, $\left.\mathrm{H}_{4 / 5}\right), 8.11\left(\mathrm{t}, J=9.0 \mathrm{~Hz}, 4 \mathrm{H}, \mathrm{H}_{3 / 6}\right), 7.49\left(\mathrm{br} \mathrm{s}, 2 \mathrm{H}, \mathrm{H}_{\gamma}\right), 7.27(\mathrm{t}, J=$ $\left.9.0 \mathrm{~Hz}, 4 \mathrm{H}, \mathrm{H}_{2 / 7}\right), 7.21$ (d, J=9.0 Hz, $\left.4 \mathrm{H}, \mathrm{H}_{1 / 8}\right), 7.13\left(\mathrm{br} \mathrm{s}, 1 \mathrm{H}, \mathrm{H}_{\mathrm{m}}\right.$ ), $7.01-6.88\left(\mathrm{~m}, 4 \mathrm{H}, \mathrm{H}_{\beta-\beta^{\prime}}\right), 6.82$ (br s, $\left.2 \mathrm{H}, \mathrm{H}_{\mathrm{o}}\right), 4.73$ (s, 6H, Me). ${ }^{13} \mathrm{C}$ NMR $\left(125 \mathrm{MHz}, \mathrm{D}_{2} \mathrm{O}, 298 \mathrm{~K}\right): \delta(\mathrm{ppm})=158.5\left(\mathrm{~s}, \mathrm{C}_{9}\right), 155.3$ $\left(\mathrm{s}, \mathrm{C}_{\mathrm{Py}}\right), 151.9,141.4,139.1\left(\mathrm{~s}, \mathrm{C}_{3 / 6}\right), 137.5\left(\mathrm{~s}, \mathrm{C}_{\gamma}\right), 135.7,129.7$ (s, $\left.\mathrm{C}_{1 / 8}\right), 127.4\left(\mathrm{~s}, \mathrm{C}_{2 / 7}\right), 127.0\left(\mathrm{~s}, \mathrm{C}_{\mathrm{o}-\mathrm{o}^{\prime}}\right), 126.4\left(\mathrm{~s}, \mathrm{C}_{\mathrm{m}}\right), 125.7,124.2$ (s, 
$\left.\mathrm{C}_{\beta / \beta^{\prime}}\right), 119.9\left(\mathrm{~s}, \mathrm{C}_{\beta / \beta^{\prime}}\right), 118.9\left(\mathrm{~s}, \mathrm{C}_{4 / 5}\right), 38.6(\mathrm{~s}, \mathrm{Me}) . \mathrm{UV} / \mathrm{Vis}\left(\mathrm{H}_{2} \mathrm{O}\right.$, $298 \mathrm{~K}): \lambda \max (\mathrm{nm})\left(\varepsilon\left(\mathrm{L} \cdot \mathrm{mol}^{-1} \cdot \mathrm{cm}^{-1}\right)\right)=296(15450), 361$ (15300), 408 (7650), 430 (7500), 453 (5000).

\section{Conclusions}

In conclusion, we successfully synthesized a new molecular tweezer incorporating two acridinium moieties bridged by a 1,3-dipyridylbenzene spacer following a three-step synthesis. In aqueous solution, this system showed its ability to selfassemble into an entwined dimer on account of $\pi$ - $\pi$ stacking and hydrophobic interactions. The 1:1 mixture of this molecular tweezer and our previously reported tweezer build on 2,6diphenylpyridyl spacer resulted in the exclusive formation of homomeric dimers in water in spite of their similar shape and size. This behaviour was the consequence of a thermodynamically controlled narcissistic recognition process as demonstrated by NMR experiments (variable temperature and competitive solvent experiments). Additionally, DFT calculations are in perfect accordance with the estimated association constants of both dimers. The stability of the dimers in water is ensured by the van der Waals forces, namely $\pi$ stacking interactions between the acridinium moieties and the spacers. Side interactions such as the $[\mathrm{N} \cdots \mathrm{H}]$ bond network in the core dimers also contribute to the dimer stability. Work is now underway to synthesize and study new generations of these bis-acridinium tweezers endowed with specific functions.

\section{Conflicts of interest}

"There are no conflicts to declare".

\section{Acknowledgements}

This work was supported by the CNRS and the University of Strasbourg. We are grateful to Dr. Lionel Allouche and to Dr Bruno Vincent (NMR Service) of the Fédération de Chimie Le Bel. We thanks the computation center of Strasbourg for computing time.

\section{Notes and references}

1 N. A. Campbell, J. B. Reece, M. R. Taylor, E. J. Simon, J. L. Dickey, Biology: Concepts and Connections, 6th ed.; CA: Benjamin/Cummings Publishing Company, San Francisco, CA, 2008.

2 (a) D. J. Cram and J. M. Cram, Science, 1974, 183, 803-809; (b) J.-M. Lehn, Science, 1985, 227, 849-856; (c) J.-M. Lehn, Angew. Chem., Int. Ed. Engl., 1990, 29, 1304-1319; (d) J.-M. Lehn, Supramolecular Chemistry: Concepts and Perspectives, Wiley-VCH, New York, NY, 1995; (e) J. Rebek Jr., Chem. Soc. Rev., 1996, 25, 255-264; (f) J. M. Spruell, Pure Appl. Chem., 2010, 82, 2281-2294.

3 (a) M. M. Conn and J. Rebek Jr., Chem. Rev., 1997, 97, 16471668; (b) J. Rotzler and M. Mayor, Chem. Soc. Rev., 2013, 42, 44-62; (c) T. Haino, T. Fujii, A. Watanabe and U. Takayanagi, Proc. Natl. Acad. Sci. U. S. A., 2009, 106, 10477-10481; (d) Y. Wang, M. Frasconi, W.-G. Liu, Z. Liu, A. A. Sarjeant, M. S.
Nassar, Y. Y. Botros, W. A. Goddard III and J. F. Stoddart, J. Am. Chem. Soc., 2015, 137, 876-885.

4 J.-M. Lehn, Chem. Eur. J., 1999, 5, 2455-2463.

5 (a) A. Wu and L. Isaacs, J. Am. Chem. Soc., 2003, 125, 48314835; (b) P. Mukhopadhyay, A. Wu and L. Isaacs, J. Org. Chem., 2004, 69, 6157-6164; (c) S. Liu, C. Ruspic, P. Mukhopadhyay, S. Chakrabarti, P. Y. Zavalij and L. Isaacs, J. Am. Chem. Soc., 2005, 127, 15959-15967; (d) P. Mukhopadhyay, P. Y. Zavalij and L. Isaacs, J. Am. Chem. Soc. 2006, 128, 14093-14102.

6 M. M. Safont-Sempere, G. Fernández and F. Würthner, Chem. Rev., 2011, 111, 5784-5814.

7 (a) Y.-R. Zheng, H.-B. Yang, B. H. Northrop, K. Ghosh and P. J. Stang, Inorg. Chem., 2008, 47, 4706-4711; (b) R. Pinalli, V. Cristini, V. Sottili, S. Geremia, M. Campagnolo, A. Caneschi and E. Dalcanale, J. Am. Chem. Soc., 2004, 126, 6516-6517; (c) E. M. Pérez and N. Martín, Chem. Soc. Rev., 2008, 37, 15121519; (d) M. Yamanaka, Y. Yamada, Y. Sei, K. Yamaguchi and K. Kobayashi, J. Am. Chem. Soc., 2006, 128, 1531-1539; (e) D. L. Caulder and K. N. Raymond, Angew. Chem. Int. Ed. Engl., 1997, 36, 1440-1442.

8 (a) D. Ajami, J.-L. Hou, T. J. Dale, E. Barrett and J. Rebek, Jr., Proc. Natl. Acad. Sci. U.S.A., 106, 10430-10434; (b) Y. Kubota, S. Sakamoto, K. Yamaguchi and M. Fujita, Proc. Natl. Acad. Sci. U.S.A., 99, 4854-4856; (c) K. A. Jolliffe, P. Timmerman and D. N. Reinhoudt, Angew. Chem. Int. Ed., 1999, 38, 933-937.

9 (a) D. Braekers, C. Peters, A. Bogdan, Y. Rudzevich, V. Böhmer and J. F. Desreux, J. Org. Chem., 2008, 73, 701-706; (b) Y. Rudzevich, V. Rudzevich, F. Klautzsch, C. A. Schalley and V. Böhmer, Angew. Chem. Int. Ed., 2009, 48, 3867-3871; (c) M. Yoshizawa, M. Nagao, K. Kumazawa and M. Fujita, J. Organomet. Chem., 2005, 690, 5383-5388; (d) S. V. Kolotuchin and S. C. Zimmerman, J. Am. Chem. Soc., 1998, 120, 9092-9093.

10 (a) S. De, K. Mahata and M. Schmittel, Chem. Soc. Rev., 2010, 39, 1555-1575; (b) R. Stiller and J.-M. Lehn, Eur. J. Inorg. Chem., 1998, 9772982; (c) J.-M. Lehn, Angew. Chem. Int. Ed., 2013, 52, 2836-2850; (d) I. Saur, R. Scopelliti and K. Severin, Chem. Eur. J., 2006, 12, 1058-1066; (e) A. M. Johnson and R. J. Hooley, Inorg. Chem., 2011, 50, 4671-4673.

11 (a) M. Rahaman Molla, A. Das and S. Ghosh, Chem. Eur. J. 2010, 16, 10084-10093; (b) K. Sugiyasu, S.-I. Kawano, N. Fujita and S. Shinkai, Chem. Mater., 2008, 20, 2863-2865; (c) J. K. Klosterman, Y. Yamauchi and M. Fujita, Chem. Soc. Rev., 2009, 38, 1714-1725.

12 S. Ghosh, A. Wu, J. C. Fettinger, P. Y. Zavalij and Lyle Isaacs, J. Org. Chem., 2008, 73, 5915-5925.

13 H.-P. Jacquot de Rouville, N. Zorn, E. Leize-Wagner and V. Heitz, Chem. Commun., 2018, 54, 10966-10969.

14 (a) S. C. Zimmerman, Z. Zeng, W. Wu and D. E. Reichert, J. Am. Chem. Soc., 1991, 113, 183-196; (b) S. C. Zimmerman and K. W. Saionz, J. Am. Chem. Soc., 1995, 117, 1175-1177; (c) S. C. Zimmerman, K. W. Saionz and Z. Zeng, Proc. Natl. Acad. Sci. U. S. A., 1993, 90, 1190-1193; (d) S. C. Zimmerman, C. M. VanZyl and G. S. Hamilton, J. Am. Chem. Soc., 1989, 111, 1373-1381; (e) S. C. Zimmerman and C. M. VanZyl, J. Am. Chem. Soc., 1987, 109, 7894-7896; (f) S. C. Zimmerman and W. Wu, J. Am. Chem. Soc., 1989, 111, 8054-8055; (g) S. C. Zimmerman, M. Mrksich and M. Baloga, J. Am. Chem. Soc., 1989, 111, 8528-8530.

15 Noteworthy, the convergent synthetic strategy employed for the elaboration of $\mathbf{2 \cdot 2} \mathrm{Cl}$ involves easier purifications (no column chromatography under argon atmosphere required)

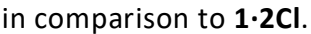

16 A. Gosset, Z. Xu, F. Maurel, L.-M. Chamoreau, S. Nowak, G. Vives, C. Perruchot, V. Heitz and H.-P. Jacquot de Rouville, New J. Chem., 2018, 42, 4728-4734.

17 Total conversion of $\mathbf{2} \cdot \mathbf{2} \mathbf{P F}_{6}$ to the corresponding chloride salt $(\mathbf{2} \cdot \mathbf{2} \mathrm{Cl})$ was confirmed by ${ }^{31} \mathrm{P}$ and ${ }^{19} \mathrm{~F}$ NMR experiments. 
18 M. Fujita, F. Ibukuro, H. Hagihara and K. Ogura, Nature, 1994, 367, 720-723.

19 UV-Vis spectra in DMSO and in $\mathrm{H}_{2} \mathrm{O}$ showed no differences in the recorded transitions (see ESI, Fig. S4.1-4.2).

20 Noteworthy, no changes were observed in the ${ }^{1} \mathrm{H} N M R$ spectrum $\left(400 \mathrm{MHz}, \mathrm{D}_{2} \mathrm{O}, 298 \mathrm{~K}\right)$ of $(2)_{2} \cdot 4 \mathrm{Cl}$ upon dilution from $1 \times 10^{-2} \mathrm{~mol} \mathrm{~L}^{-1}$ to $1 \times 10^{-3} \mathrm{~mol} \mathrm{~L}^{-1}$ (see ESI, Fig. S3.5).

21 See ESI for computational details.

22 A. Gosset, Z. Xu, F. Maurel, L.-M. Chamoreau, S. Nowak, G. Vives, C. Perruchot, V. Heitz and H.-P. Jacquot de Rouville, New J. Chem., 2018, 42, 4728-4734.

23 Y. Cohen, L. Avram and L. Frish, Angew. Chem. Int. Ed., 2005, 44, 520-554.

24 M. Holz, X. Mao, D. Seiferling and A. Sacco, J. Chem. Phys., 1996, 104, 669-679. 